Article

\title{
Assessing Water Scarcity Using the Water Poverty Index (WPI) in Golestan Province of Iran
}

\author{
Masoud Jafari Shalamzari (iD) and Wanchang Zhang * \\ Key Laboratory of Digital Earth Science, Institute of Remote Sensing and Digital Earth, \\ Chinese Academy of Sciences, Beijing 100094, China; msdpardis@gmail.com \\ * Correspondence: zhangwc@radi.ac.cn; Tel.: +86-010-82178131
}

Received: 13 June 2018; Accepted: 6 August 2018; Published: 13 August 2018

\begin{abstract}
Population growth and rising water demand, climate change, severe droughts, and land-use changes are among the top severe issues in Iran. Water management in this country is sectoral and disintegrated. Each authority evaluates water based on its final intention and there is no commonplace indicator for evaluation programs. In this research, we used the Water Poverty Index (WPI) to map the status of water scarcity in a north-eastern province of Iran. Water poverty was measured based on five components of "Resources", "Access", "Capacity", "Use", and "Environment". The scores on each component were then aggregated using the weighted multiplicative function, assuming equal weights for all components. The overall WPI was evaluated to be 41.1, signaling an alarming and serious water poverty in the study area. Based on the results, Azadshahr (29.1) and Gorgan (61.6) districts had the worst and the best conditions among all cases, respectively. To better understand the importance of WPI components, four weighting alternatives were used; however, none of them resulted in a tangible improvement of WPI index. The cross-correlation between the components was also evaluated, with Access and Capacity showing significant results. Leaving out "Capacity", however, reduced WPI by 8.1. In total, "Access", "Capacity", and "Use" had the highest correlation with WPI, implying that any attempt to improve water poverty in the province must firstly tackle these issues. This study showed that WPI is an effective indicator of water scarcity assessment and could be used to make priorities for policy-making and water management.
\end{abstract}

Keywords: Iran; access; environment; availability; scarcity; policy

\section{Introduction}

Water is the fundamental basis of life and should be regarded as an inevitable necessity of sustainable development. Water is also an integral part of social and economic development in any country. Water resources are unevenly distributed on earth. While some countries receive abundant precipitation, others may fall extremely short of water. More than two billion people live in highly water-stressed areas because of this uneven distribution of water resources [1].

Water is becoming a rare commodity for most people [2]. This is especially the case in the populated arid areas of the Central and West Asia and North Africa, with less than $1000 \mathrm{~m}^{3}$ /capita/year water availability [3]. Burgeoning population, remarkable rise in water demand and water shortage are all the facts of the current era. The demand for water is highly likely to grow in the 21st century which calls for a wise management of scarce water resources [4]. For instance, Biswas [4] reported a 10-fold higher water demand during this century. Vörösmarty et al. [5] believed that by 2025, the rise in water demand will outweigh the impact of global warming on the global hydrological cycle. The main challenges ahead related to water are freshwater scarcity, lack of access to adequate and clean drinking water and sanitation, deterioration of water quality, political fragmentation in water resources management, 
decline of financial resources for water development, threat to world peace and security, and continued lack of awareness of the magnitude of the problem by policy and decision makers [6,7].

While anticipating a harsher water scarcity for the coming decades, one must not overlook the intensification of competition over water sources, which might stimulate armed conflicts. The competition over water is more probable in low to moderate income countries which are projected to have less runoff flow and more flash floods in the coming decades [8]. This conflict will become a matter of the national security and might turn into armed and military confrontations $[9,10]$. For instance, the political tensions between Arabs and Israelis, Indians and Bangladeshi, Americans and Mexicans and riparian states of the Nile River are all the early warnings of a significant challenge ahead [11]. De Stefano et al. [12] believe that changes in terrestrial water storage, water variability, per-capita gross national income, national and civil conflicts, and recent disputes over water sources could result in the intensification of tensions over transboundary water sources in the near future. They have also argued that several basins in south-west Asia are vulnerable to such tensions, which is also supported by Feitelson and Tubi [13].

Over the past few decades, many indicators have been developed to assess water scarcity and vulnerability and to assist managers and the public to get a clearer picture of the prevailing status of the system. Indicators are used to describe the system of interest and to elicit information from a large amount of data. Indicators must be simple, measurable, robust, and relevant to the objectives of the operator. The main roles of indicators are to simplify the data, quantify parameters and communicate information [14]. Brown and Matlock [15] provided a very detailed description of the available water scarcity indicators, by dividing all the indices into four general categories related to the basic human requirements (Falkenmark indicator [16], the Social Water Stress Index [17], and Water Resources Availability and Cereal Import [18]), water resources vulnerability indices (Water Resources Vulnerability Index [19], the Index of Local Relative Water Use and Reuse [5,9], the Watershed Sustainability Index [20], the Water Supply Stress Index [21], and Physical and Economical Water Scarcity (developed by the International Water Management Institute (IWMI)), environmental water requirements (Population Growth Impacts on Water Resource Availability [22], and the Water Stress Indicator (WSI) [23]), and life cycle analysis and water footprint assessment (Water Scarcity Index [24] and Water Footprinting Index [24]). As Brown and Matlock [15] further described, the purpose of the indices related to human water requirements is to estimate the available water resources as a function of population size on a national scale. Accordingly, if there is not enough water for the population, the area will be considered water scarce. Compared to the water availability indices which provide a fixed value for the amount of water available, water resources vulnerability indices both consider water availability and water demand, which can be divided into smaller agricultural, industrial, and domestic categories. In addition to water supply and demand assessment, indices related to environmental water requirements consider the amount of water required to maintain the ecosystem's integrity. Although estimating the ecological water demand is challenging, considering both water and ecosystem as a unit increases the validity of the results of water scarcity assessment. The fourth category which concerns life cycle analysis and water footprint assessment, evaluates water use effects in response to consumption of goods and services. The fourth category thus far provides a more comprehensive picture of water scarcity by incorporating the impact of water consumption on human health, ecosystem quality and resources [12].

Water scarcity is mainly a function of the amount of water available and the number of people demanding it [14]. However, except for a few cases, most of the indicators provided above mainly consider the physical availability of water, without directly addressing the importance of external social and economic forces [25]. Considering only the physical water scarcity can be misleading as some countries facing severe water scarcity can address the problem by importing virtual water [26,27]. Feitelson and Tubi [13] mentioned the rich arid countries as oil states (mainly along the Persian Gulf) which are capable of water provision via importing virtual water. Moreover, the thresholds set in most of the introduced indicators is applicable to human survival or food production, while nowadays food is increasingly supplied through market mechanisms. Water availability should 
be approached from both water quantity and quality perspectives, which is not sufficiently reflected in the introduced indicators.

Physical water scarcity is also strongly connected to poverty, and adequate access to safe water is regarded as a human right [28]. For instance, Feitelson and Chenoweth [14] defined water poverty as a situation where a nation or a region cannot afford the cost of sustainable clean water to all people at all times. Insecure water infrastructures and networks could also exacerbate physical water poverty [29,30]. Lawrence et al. [31] believe that inadequate water availability and insufficient income both lead to water scarcity. In order for the indices to be more compliant with reality, Ohlsson and Turton [32] emphasized the importance of the adaptive capacity. To Gallopín [33], adaptive capacity is the system's ability to adjust to a disturbance, moderate potential damage, take advantage of opportunities, and cope with the consequences of a transformation that occurs. OhIsson [34] proposed to use the Human Development Index (HDI) components when assessing water scarcity in the form of the social water scarcity index. A broader perspective has been adopted by Salameh [35], who defined water poverty as the ratio of the amount of available renewable water to the amount required to cover food production and the household uses of one person in one year under the prevailing climate condition. One of the main advantages of the new index was considering the severity of water scarcity from the household perspective [14]. Sullivan et al. [36] finally introduced the most recent definition of water poverty and drew fine distinctions between different components of water-related poverty [37]. Accordingly, water poverty was defined as an aggregated index of the percentage of water used in a region combined with the percentage of the population with access to safe water and sanitation, and the percentage of the population with easy access to water for domestic use [14,36]. The Water Poverty Index (WPI) is mainly developed for water scarcity assessments at the scale of local communities, but the ability to adapt this index for different scales is one of its advantages. For instance, Pérez-Foguet and Garriga [38] proposed a watershed-based WPI and successfully piloted it at a Peruvian watershed as a case study.

The WPI has found great relevance in policy-making as an effective water management tool, particularly in resources allocation and prioritization processes [38-40]. In this research, we have adopted the WPI to evaluate the intensity of water shortage and make prioritization of water-poor areas in a north-eastern province of Iran. There is not enough evidence on the application of the WPI in Iran. In one of the few cases, Shirdeli [41] evaluated water scarcity in Iran (in general) and the Qaraqom Watershed (as a case study) using different internationally known indices including WPI and found that among all indices WPI is a suitable index for water scarcity assessments on national and local scales. The main objective of this paper is to evaluate the status of water poverty in Golestan Province of Iran. Iran is selected in this study because of the intensity of water scarcity in this country. Iran's major rivers such as Karoun and Zayendehroud are almost dried and it has also lost one of the largest lakes in the Middle East, Lake Urmia. Iran has also difficulty providing drinking water because of the significant population growth and shrinkage of water sources over the past decades as the result of overexploitation of water resources and prolonged drought episodes. Water scarcity evaluation in Iran is mainly based on the physical quantity of water in each province while neglecting other important economic and social driving forces of water scarcity. Therefore, in this paper, we tried to use WPI as a comprehensive water scarcity evaluation tool in Golestan Province of Iran with a large socio-economic, topographic, and environmental diversity to demonstrate its applicability for other parts of the country. The geographic scale of the study was selected since water management in Iran is administered within the boundary of a province, and not the scale of river basins and watersheds, mainly because the boundary for which governmental organizations have authority in is defined as provinces by the law. The items used to estimate the WPI index were identified in close collaboration with the scientific community working in the field of water management in Golestan Province. It is also attempted to illustrate how improving water poverty components can help reduce water scarcity in different districts of the province. We believe that (up to the time of writing) the experimental work presented here provides one of the first comprehensive applications of WPI indicator in Iran which makes this paper unique in this respect. 
The remaining part of the manuscript proceeds as follows: a detailed description of the study area, the structure of the WPI index and the list of the adopted indicators are provided in the next section. In the results section, we will report on the differences between the districts studied in terms of the selected indicators and the total scarcity itself. In the discussion section, the results will be compared with those of others, and a practical conclusion will be provided afterward in the conclusion section.

\section{Materials and Methods}

\subsection{Study Area}

Golestan Province covering almost $21,000 \mathrm{~km}^{2}$, is in the north-eastern part of Iran and is home to 1.86 million people (Figure 1). This area enjoys a mild weather and a temperate climate. One of the main characteristics of precipitation variability in Golestan Province is its distinct variation in the north-south and west-east directions. Based on the 30-year average (1987-2017) of weather records provided by the Iran Meteorological Organization, mean annual precipitation in the north-south direction ranges from $290 \mathrm{~mm}$ at Marze Artesh Station (north) to $600 \mathrm{~mm}$ at Shirinabad Station (south) covering a distance of $50 \mathrm{~km}$, and in the west-east direction from $460 \mathrm{~mm}$ at Bandar Turkmen Station (west) to $370 \mathrm{~mm}$ at Maraveh Tappeh Station (east), covering a distance of $200 \mathrm{~km}$ (Figure 1). Likewise, mean annual temperature ranges from 18.1 to $14.9^{\circ} \mathrm{C}$ in the north-south direction and from 18.2 to $18{ }^{\circ} \mathrm{C}$ in the west-east direction. This province has diverse topographic features including the high Alburz Mountains to the south, salt marshes and low lands to the north, the coastal areas along the Caspian Sea to the west and the loess hills to the west. The north-south and west-east directions elevation changes range from -10 to $2460 \mathrm{~m}$ and -26 to $1110 \mathrm{~m}$, respectively. Gorgan Roud and Atrak are the two longest rivers in Golestan Province. These two rivers originate from the mountains of the Northern Khorasan Province. Gorgan Roud flows through the Gorgan Plain for a distance longer than $250 \mathrm{~km}$ before it reaches the Caspian Sea. Atrak Roud, which acts as a border barrier between the two countries of Iran and Turkmenistan, travels for longer than $670 \mathrm{~km}$ draining a basin of $27,300 \mathrm{~km}^{2}$. The average annual discharges of these two rivers are $1.08 \times 10^{8} \mathrm{~m}^{3} /$ year and $4.7 \times 10^{8} \mathrm{~m}^{3} /$ year, respectively [42]. Because of the heavy exploitation of the Atrak river for agricultural purposes, it only flows to the Caspian Sea in case of flood events. The other rivers of the province are mainly saline or seasonal and have little or no importance for irrigation or drinking water purposes. Major land-use types include agricultural lands (35\% including irrigated, rain-fed, orchards), rangelands (42\%), forests (22\%), salt marshes, playas and residential areas (1\% in total) [42]. Based on the latest statistics, the population of Golestan Province has increased by $9.4 \%$ since the last census in 2011. Administratively, the area is divided into 14 districts, 14 cities and 279 villages most of which distributed in a narrow band in the middle of the province with a very sharp reduction in population density traveling from south to north and from west to east. Groundwater is the main source of water for drinking purposes and agricultural activities. However, in parts in the north of the province, some villages have historically used rainwater harvesting structures to compensate a part of their demand for drinking and livestock watering. However, a sharp reduction in precipitation and severe droughts in recent years have remarkably diminished the performance of these structures [43]. Due to poverty, lack of enough water, and unemployment, Golestan Province has recently experienced a major shift in migration from small villages to larger population centers, especially the capital city, Gorgan. Overexploitation of groundwater aquifers has been simultaneous with a sharp drop of groundwater levels, saline water intrusion, loss of water quality and land subsidence. On the other hand, lack of sufficient precipitation has limited the natural rate of recharge of these water sources. Therefore, water shortage is expected to become harsher and more severe in the coming years [44]. Heavy migration from villages to cities might cause different social and economic issues in the future. Therefore, there is an urgent need of planning and policy-making before the situation becomes uncontrollable. One of the main problems in water management in Iran in general, and Golestan Province in particular, is its fragmented water governance structure [45]. Iran Meteorological Organization is in charge of collecting data on precipitation. The Ministry of Energy 
is responsible for policy-making for water and water provision for domestic, industrial, and agricultural sectors, while at the same time collecting data on water resources, treating wastewater, and generating hydropower. Among the objectives of the Forests, Range and Watershed Management Organization, water conservation and watershed management could be mentioned. The overlapping responsibilities of different organizations has made integrated water management a complex task in this country [46].

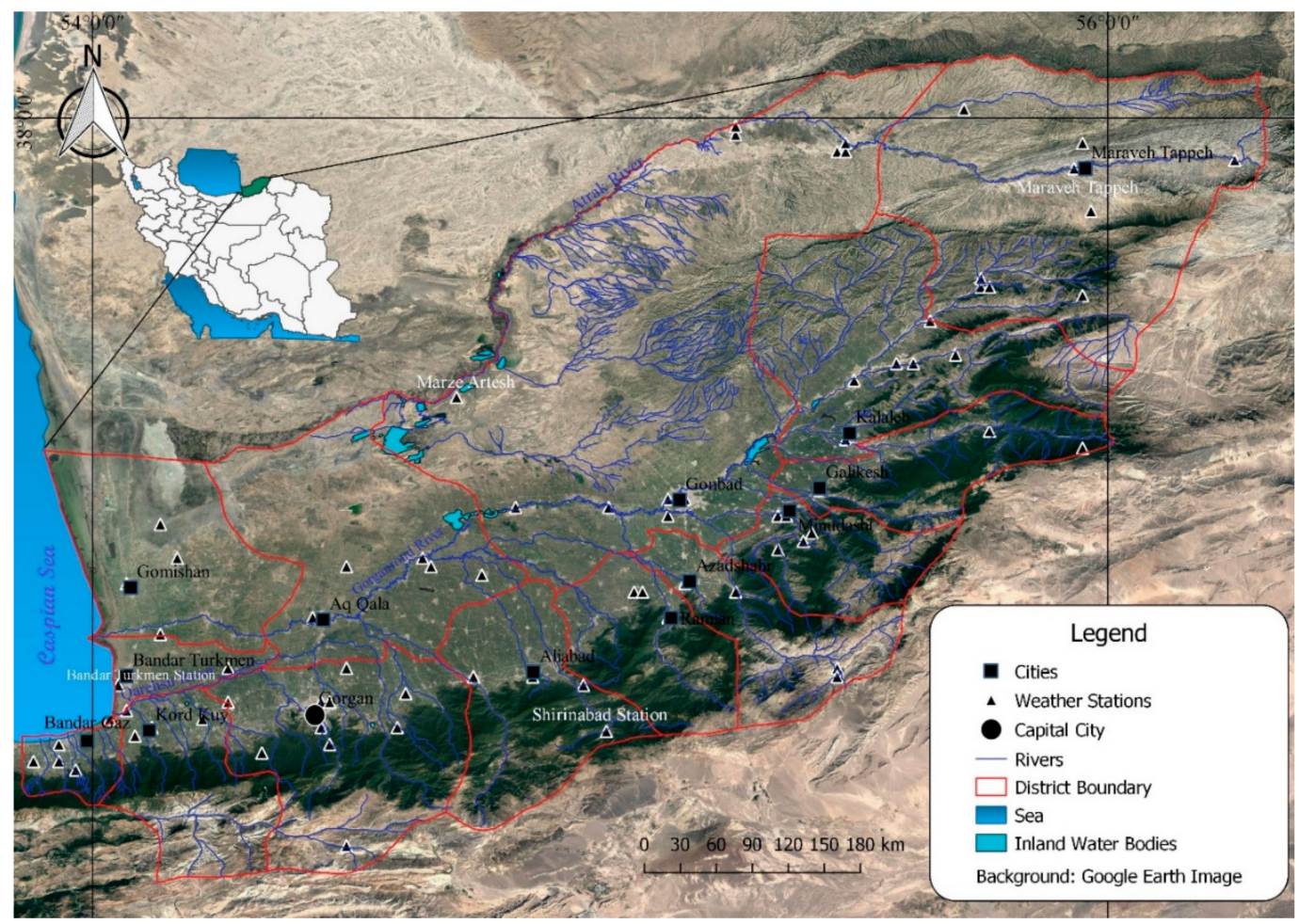

Figure 1. Location of the study area relative to Iran's boundary along with the districts of Golestan Province.

\subsection{Water Poverty Index}

To evaluate water scarcity in Golestan Province, we used the Water Poverty Index (WPI) proposed by Sullivan [47]. The WPI index is composed of five components:

- $\quad$ Resources (R): the amount of water available, by considering the seasonal and inter-annual variability of water availability and quality;

- Access (A): how well provisioned the population is, including domestic and agricultural uses;

- Capacity (C): the ability to manage water resources, based on education, health, and access to financing;

- $\quad$ Use (U): the use of water and its contribution to the economy;

- Environment (E): which attempts to capture the environmental impact of water management to ensure the long-term ecological integrity.

To evaluate each WPI component, we used a set of indicators as provided in Table 1. The indicators are identified in close collaboration with the scientific community working in the field of water resources and watershed management in Golestan Province. Table 1 also provides the details on data sources, duration and the scale used for collecting each data source. 
Table 1. WPI component variables for water scarcity assessment over the study area.

\begin{tabular}{|c|c|c|c|c|}
\hline WPI Component & Indicator Used & Year & Scale & Source \\
\hline Resources $\left(R_{i}\right)$ & $\begin{array}{l}\text {-Per-capita annual water } \\
\text { resources }\left(R_{1}\right) \\
\text {-Precipitation Coefficient of } \\
\text { Variation }(C V)\left(R_{2}\right)\end{array}$ & $\begin{array}{l}2001-2014 \\
1987-2017\end{array}$ & Catchment/District & $\begin{array}{l}\text { Regional Water } \\
\text { Company of } \\
\text { Golestan Province } \\
\text { WorldClim }\end{array}$ \\
\hline Access $\left(A_{i}\right)$ & $\begin{array}{l}\text {-Access to clean water as percent } \\
\text { of the population having piped } \\
\text { water supply }\left(A_{1}\right) \\
\text {-Access to sanitation as a percent } \\
\text { of the population with improved } \\
\text { sanitation services }\left(A_{2}\right)\end{array}$ & 2016 & District & $\begin{array}{l}\text { Golestan Province } \\
\text { Territorial Planning }\end{array}$ \\
\hline Capacity $\left(C_{i}\right)$ & $\begin{array}{l}\text {-Literacy Rate }\left(C_{1}\right) \\
-\% \text { of the population with access } \\
\text { to health centers }\left(C_{2}\right) \\
-\% \text { of the population with access } \\
\text { to electricity }\left(C_{3}\right) \\
-\% \text { of households receiving a } \\
\text { pension, remittances, or } \\
\text { wages }\left(C_{4}\right)\end{array}$ & 2016 & District & $\begin{array}{c}\text { Golestan Province } \\
\text { Territorial Planning, } \\
\text { National Population, } \\
\text { and Housing Census } \\
\text { Statistics Yearbook of } \\
\text { the Ministry of } \\
\text { Cooperatives, Labor, } \\
\text { and Social Welfare }\end{array}$ \\
\hline Use $\left(U_{i}\right)$ & $\begin{array}{l}\text {-Domestic water consumption } \\
\text { rate }\left(U_{1}\right) \\
\text {-Livestock water use, based on } \\
\text { livestock holdings and standard } \\
\text { water needs }\left(U_{2}\right) \\
\text {-Agricultural water use expressed } \\
\text { as the proportion of irrigated land } \\
\text { to the total cultivated area }\left(U_{3}\right) \\
\text {-Industrial water use }\left(U_{4}\right)\end{array}$ & 2014 & District & $\begin{array}{l}\text { Rural and Urban } \\
\text { Water and } \\
\text { Wastewater } \\
\text { Authority } \\
\text { Agricultural Jihad } \\
\text { Organization }\end{array}$ \\
\hline Environment $\left(E_{i}\right)$ & $\begin{array}{l}\text {-Risk of desertification }\left(E_{1}\right) \\
\text {-Risk of erosion }\left(E_{2}\right) \\
\text {-Risk of flooding }\left(E_{3}\right)\end{array}$ & 2015 & District & $\begin{array}{l}\text { Faraj Zadeh et al. } \\
\text { [48] }\end{array}$ \\
\hline
\end{tabular}

\subsection{WPI Components and Normalization Approaches}

In total, 15 indicators were selected to estimate water poverty in different districts of Golestan Province. What follows is the description of each of the components along with the approach adopted for data normalization.

\subsubsection{Resources}

This component represents the physical availability of both surface and groundwater resources, taking into account variability and quality as well as the total amount of water [49]. The "Resources" component was evaluated by considering both the availability and variability of water resources.

\section{Availability}

The amount of readily available fresh water was measured in quantity and quality from both surface water and groundwater resources. Data for this component was obtained from the Regional Water Company of Golestan Province for 2001-2014. For the groundwater resources, we considered the average annual discharge of Kariz strings (a system of underground tunnels and networks to collect water from water-rich layers into a single or multiple ground surface drainage points; a total of 152 strings), springs (a total of 3627) and the average annual water abstraction from wells (a total of 22,187 wells). Water quality of these resources was evaluated using the Schuller Water Quality Classification (see [50]). Schuller Water Quality Classification method is commonly used for water quality classification with respect to drinking quality standards. We used the $\mathrm{Na}^{+1}, \mathrm{Cl}^{-1}, \mathrm{SO}_{4}{ }^{2-}$, total dissolved solids (TDS) and water hardness parameters to evaluate the volume of suitable water for drinking. According to the Schuller Classification Method, water sources were classified into six categories ranging from non-potable to acceptable quality, and only the volume of water in the acceptable quality status was 
considered for further measurements. The amount of water from three groundwater sources was then aggregated at the scale of districts. However, as surface water sources from rivers were not readily convertible into district scale, specific discharges were estimated at each station (using the data from 26 hydrometer stations) and multiplied by the area of the corresponding district (see [51]). From the total number of 26 stations (Figure 2), the discharge from four stations on the River Atrak was discarded because of low water quality. We used the minimum and maximum values of water availability for data normalization as follow:

$$
R_{1}=\frac{R_{1}-\min \left(R_{1}\right)}{\max \left(R_{1}\right)-\min \left(R_{1}\right)} \times 100,
$$

where $R_{1}$ is the normalized water availability, ranging between 0 and 100, respectively indicating the worst and the ideal water availability conditions.

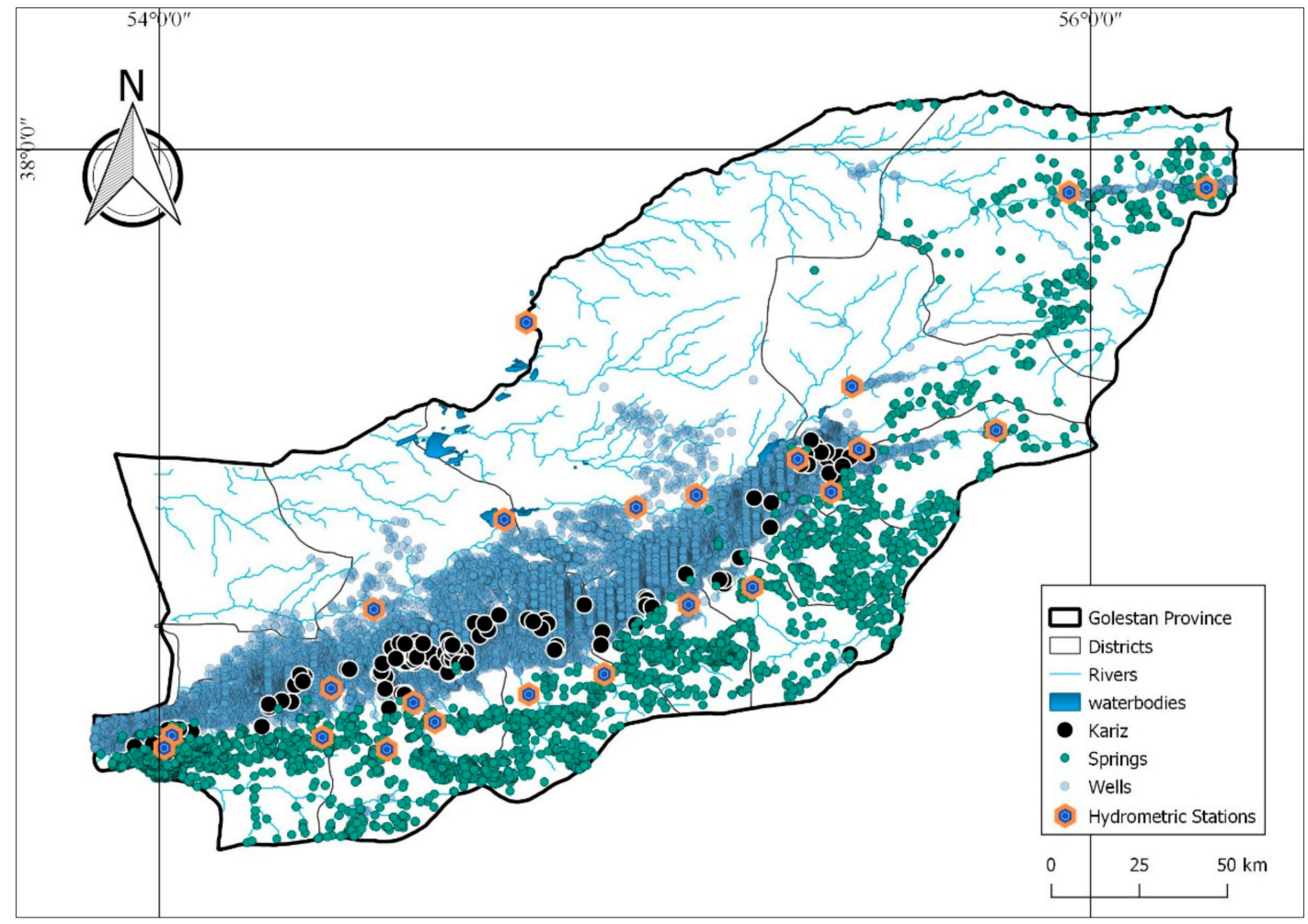

Figure 2. Surface and groundwater resources of Golestan Province.

Variability

We used the precipitation Coefficient of Variation $(\mathrm{CV})$ as a proxy for water variability. The CV data was obtained from the WorldClim (website at http://www.worldclim.org) for 1990-2017. WorldClim is a set of global climate layers (gridded climate data) with a spatial resolution of about $1 \mathrm{~km}^{2}$. Any value above the $\mathrm{CV}$ values of $30 \%$ represents vulnerability and water resources unreliability [52]. Accordingly, the following equation was used to normalize CV values:

$$
R_{2}=100-\left(\frac{R_{2}-30}{\max \left(R_{2}\right)-30}\right)
$$

where $R_{2}$ represents the normalized CV at district $i$, ranging in value from 0 to 100 . 


\subsubsection{Access $\left(A_{i}\right)$}

We approached the "Access" component from two aspects, namely access to drinking water supply and access to improved sanitation. Data for this component was obtained from the Golestan Province Territorial Planning [42] for the year 2016. Access to these two items was evaluated using the proportion of the population with access to safe water supply network and improved sanitation facilities (sewage collection network) as follows:

$$
A_{1,2}=\frac{P_{d-s}}{p} \times 100
$$

where $A_{1,2}$ is the normalized score for the "Access" component, $P_{d-s}$ is the proportion of the population having access to safe drinking water and sanitation, and $p$ is the total population at the district of interest.

\subsubsection{Capacity $\left(C_{i}\right)$}

The indicators used under this component were literacy level, percent of households receiving a pension, remittances or wages, percent of the population with access to electricity, and population with access to primary medical services (number of active health centers was used as a proxy). Data for this component was obtained from Golestan Province Territorial Planning [42], National Population and Housing Census, and the Statistics Yearbook of the Ministry of Cooperatives, Labor, and Social Welfare for the year 2016. Literacy rate was measured as the number of literate people higher than 15 years of age with the ability to read and understand the issues related to water as:

$$
C_{1}=\frac{p}{P} \times 100,
$$

where $C_{1}$ is the normalized index, $p$ is the number of literate people, and $P$ is the total population of the district. Access to electricity (electrification rate) and access to health services were normalized using the following equations:

$$
C_{2}=\frac{(R M \times R P)-\min (R M \times R P)}{\max (a R M \times R P)-\min (R M \times R P)} \times 100,
$$

where $C_{2}$ is the normalized score for the number of primary health centers, $R M$ is the relative frequency of the number of health centers and $R P$ is the relative frequency of population of the district.

$$
C_{3}=\frac{z-\min z}{\max z-\min z} \times 100,
$$

where $C_{3}$ is the normalized score for the electrification rate, and $z$ is calculated as the ratio between the number of households with access to electricity in the district over the total population of that district.

The subcomponent "Receiving money in the form of pension, remittance or wages" was normalized using the following equation:

$$
C_{4}=\frac{p_{r}}{P_{t}} \times 100,
$$

where $C_{4}$ is the normalized score for the number of households receiving pension, remittance, and wages, $p_{r}$ is the number of households receiving the fund, and $P_{t}$ is the total number of households in that district.

\subsubsection{Use $\left(U_{i}\right)$}

To assess the level of water use, we divided the consumption level into three parts of domestic water use, industrial water use and agricultural water use. Data for this component was obtained 
from the Rural and Urban Water and Wastewater Authority and Agricultural Jihad Organization for the year 2014. Domestic water use was measured based on the volume of water consumed from main supply network as follows:

$$
U_{1}=\frac{a-\min (a)}{\max (a)-\min (a)} \times 100 ，
$$

where $U_{1}$ is the normalized score for domestic water supply and $a$ is the total water used for domestic purposes. To estimate the amount of water used for domestic animals $\left(U_{2}\right)$, the number of domestic animals (goat, sheep, cattle) in each district was multiplied by its corresponding standard water use, and the final score was standardized similar to $U_{1}$. Agricultural water use $\left(U_{3}\right)$ was estimated as the ratio between irrigated land and the total area of cultivated land in each district, similar to Sullivan and Meigh [40]. This index was normalized identical to $U_{1}$ except for that $a$ is the ratio between the area of the irrigated to rain-fed lands. Water use for the industrial sector $\left(U_{4}\right)$ was estimated by including the water abstracted from wells plus the water consumed from the main water supply system. The same approach to $U_{1}$ was used to normalize the score on this component.

\subsubsection{Environment $\left(E_{i}\right)$}

To assess the status of this component, we used the results of the study of Faraj Zadeh et al. [48] in terms of desertification $\left(E_{1}\right)$, flooding $\left(E_{2}\right)$ and erosion $\left(E_{3}\right)$. The status of each of the hazards in Golestan was provided on a standard 1-5 scale from very low to very high intensities, and the results were integrated for each district as the geometric average of the underlying polygons. The scores obtained for each district was then standardized using the following equation:

$$
E_{i}=100-\left(\frac{a_{i}-\min \left(E a_{i}\right)}{\max \left(a_{i}\right)-\min \left(a_{i}\right)} \times 100\right),
$$

where $E_{i}$ is the normalized score obtained for each of the subcomponents of the environment (i.e., desertification, flooding, and erosion) and a is the score obtained for each subcomponent in each district.

\subsection{Aggregation}

The weighted multiplicative function is the most appropriate aggregation method for calculating WPI from its five components [37] as follows:

$$
\mathrm{WPI}=\prod_{i=R, A, C, U, E} X_{i}^{w i}
$$

where WPI is the water poverty index for an arbitrary location, $X_{i}$ is the $i$ th component of the WPI (R, $\mathrm{A}, \mathrm{C}, \mathrm{U}, \mathrm{E})$ function, and $w$ is the weight assigned to each component. Each of the components might or might not include subcomponents. Again, the subcomponents are combined using the weights assigned to them based on their relative importance. For estimation of water poverty, different weighting systems could thus be employed to indicate the importance of each variable, although equal indicator weights are preferred [37]. The final WPI indicator ranges from 0 to 100, where zero and 100 indicate the worst and the ideal situations. In reality, though, absolute zero and 100 almost never occur, so that the real WPI is higher and not including zero, as well as lower and not including 100.

\subsection{Sensitivity Analysis}

In the analysis, it was assumed that all components are of equal importance for the final WPI value. However, it is important to evaluate different weighting alternatives to see the enhancement of which component can help improving water poverty in the study area. Therefore, similar to Van Ty et al. [53], the weight of different components were altered. For this purpose, we considered three alternative weighting scenarios as given in Table 2. As the total amount of water is constant and cannot be directly improved, the weights were only altered for the "Access", "Capacity", "Use" and "Environment" 
components. To avoid redundancy in using the components of WPI, the cross-correlation between different components was also evaluated using the Pearson correlation coefficient.

Table 2. Alternatives to equal weighting for the estimation of WPI in Golestan Province's districts.

\begin{tabular}{ccccccc}
\hline \multirow{2}{*}{ Alternative } & \multicolumn{5}{c}{ Relative Weight } & \multirow{2}{*}{ MWPI } \\
\cline { 2 - 5 } & R & A & C & U & E & \\
\hline 1 & 1 & 2 & 2 & 2 & 1 & 30.4 \\
2 & 1 & 2 & 2 & 3 & 1 & 27.5 \\
3 & 1 & 2 & 2 & 1 & 1 & 27.3 \\
4 & 1 & 2 & 2 & 1 & 2 & 29.2 \\
\hline
\end{tabular}

\section{Results}

\subsection{WPI Components}

In this research, we estimated the level of water scarcity in different districts of Golestan Province of Iran using the WPI. The results of the normalized scores obtained for each subcomponent are provided below.

\subsubsection{Resources}

The results obtained for water availability at each district in Golestan Province are provided in Figure 3. Water resources are divided into four categories of rivers, wells, Kariz, and springs. The black squares indicate the level of per-capita water availability in each district. The Falkenmark's threshold, which is shown as a guide to illustrate physical water scarcity is indicated by a dashed line. As shown in Figure 3, the highest share of water availability comes from the river sources. However, according to the Golestan Province Territorial Planning [42], merely 54\% of the total amount of river flow is utilized, most of which used for agricultural purposes. Only $18 \%$ of the drinking water of the province is supplied by surface water. Wells are the common sources of water in all districts; having the largest share in water provision in Aliabad. Bandar Turkmen has the least diversity of water resources, only having access to wells for its water provision, followed by Gomishan and Aq Qala, which can increase vulnerability to water scarcity in these districts. Kariz, as a sustainable means of water provision, still provides the largest share of water in Golestan Province, but its application is adversely affected by the introduction of drilling technologies which could in a short time tap into deep aquifers. Springs have the smallest share of water supply in Golestan. What stands out in Figure 3 is the dependency of all districts on groundwater sources. This dependency (which will result in the depletion of groundwater resources) along with frequent and prolonged drought episodes in Iran could be regarded as the early warnings of physical water scarcity in this province in the near future. In terms of per-capita water resources availability, Gomishan $\left(1715 \mathrm{~m}^{3}\right.$ per capita), Aq Qala (1307 $\mathrm{m}^{3}$ per capita), Maraveh Tappeh (1179 $\mathrm{m}^{3}$ per capita) and Aliabad $\left(888 \mathrm{~m}^{3}\right.$ per capita) had the highest levels while Bandar Gaz $\left(2.9 \mathrm{~m}^{3}\right.$ per capita) and Bandar Turkmen $\left(0.3 \mathrm{~m}^{3}\right.$ per capita) had the worst conditions. Aq Qala and Bandar Turkmen are two adjacent districts while having significantly different water availability. This is mainly because of the River Gorgan Roud which passes through the Aq Qala district. In terms of physical water scarcity, except for Gomishan, Maraveh Tappeh, Aq Qala and Aliabad which lie very close to the Falkenmark Threshold, the rest of the province faces severe water scarcity. Water resources reliability which is estimated based on the precipitation CV ranged between $42.9 \%$ in Bandar Gaz and $67.4 \%$ in Galikesh as the best and worst conditions, respectively. The precipitation coefficients of variation are provided in Table 3. 


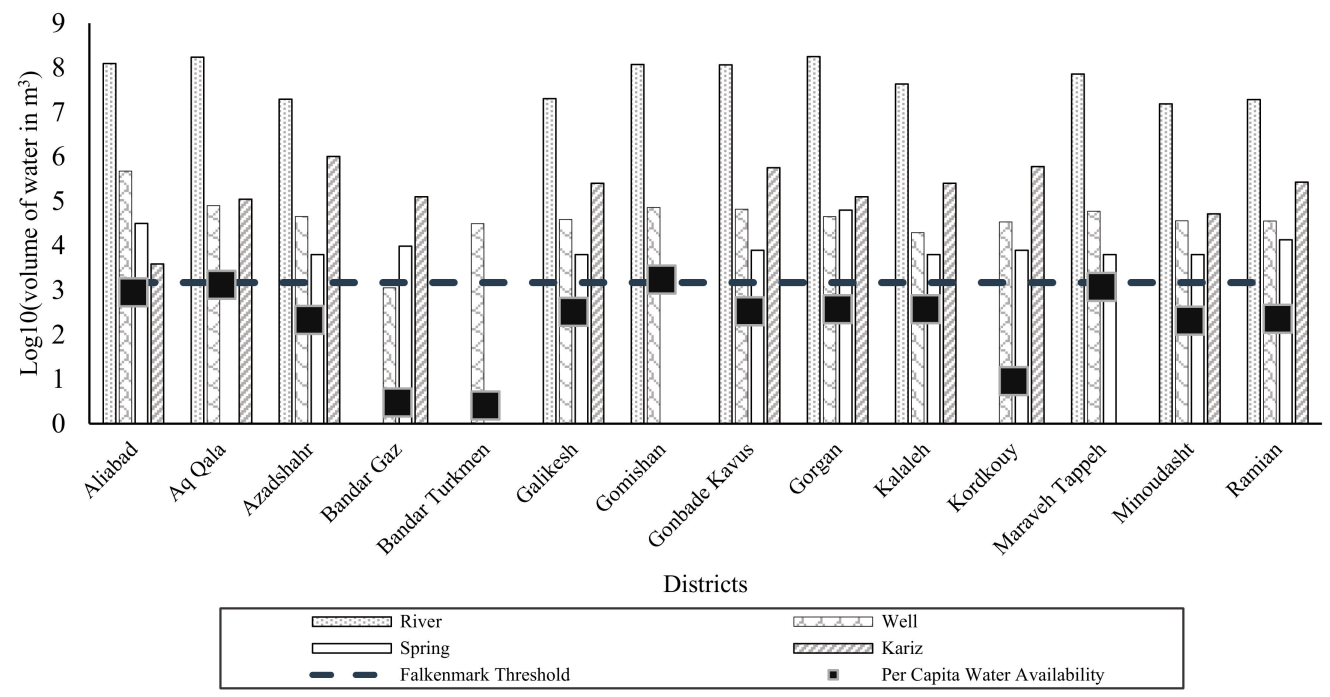

Figure 3. Water availability in different districts of Golestan Province along with per-capita water availability shown in black squares. The dash-line indicates the Falkenmark Threshold which is used to illustrate the status of physical water scarcity in different districts. The y-axis represents the logarithm of available water volume in square meters for better comparison between surface water and groundwater sources.

Table 3. Precipitation coefficient of variation in different districts of Golestan Province.

\begin{tabular}{cc}
\hline Districts & Precipitation Coefficient of Variation (\%) \\
\hline Aliabad & 60.1 \\
Aq Qala & 49.2 \\
Azadshahr & 66.4 \\
Bandar Gaz & 42.9 \\
Bandar Turkmen & 44.2 \\
Galikesh & 67.4 \\
Gomishan & 44.1 \\
Gonbade Kavus & 61.2 \\
Gorgan & 56.3 \\
Kalaleh & 66.6 \\
Kordkouy & 53.7 \\
Maraveh Tappeh & 64.6 \\
Minoudasht & 66.8 \\
Ramian & 63.2 \\
\hline
\end{tabular}

\subsubsection{Access}

Table 4 provides the status of different districts in terms of the "Access" component. All districts had high levels of water supply component. The highest proportion of the population with access to main water supply system (100\%) was obtained in Bandar Gaz and Kordkouy districts, with Galikesh (by 93.4\%) having the lowest rank among all districts. However, when it comes to access to improved sanitation services, except for four districts (i.e., Bandar Gaz, Bandar Turkmen, Gorgan, Kordkouy), the rest had no access to improved sanitation (sewer collection system). Almost all the population have access to basic sanitation services, but we considered sewer collection and treatment services to be the improved sanitation components under WPI. 
Table 4. The status of the "Access" component in different districts of Golestan Province.

\begin{tabular}{cccc}
\hline Districts & Total Population & $\begin{array}{c}\text { \%Population with Access to } \\
\text { Main Water Supply }\left(\mathbf{A}_{\mathbf{1}}\right)\end{array}$ & $\begin{array}{c}\text { \%Population with Access to } \\
\text { Improved Sanitation Services }\left(\mathbf{A}_{\mathbf{2}}\right)\end{array}$ \\
\hline Aliabad & 140,709 & 99.0 & - \\
Aq Qala & 132,733 & 99.5 & - \\
Azadshahr & 96,803 & 99.6 & - \\
Bandar Gaz & 46,130 & 100.0 & 16.2 \\
Bandar Turkmen & 79,978 & 99.6 & 5.7 \\
Galikesh & 63,173 & 93.4 & - \\
Gomishan & 68,773 & 98.9 & - \\
Gonbade Kavus & 348,744 & 99.6 & 7.4 \\
Gorgan & 480,541 & 99.3 & - \\
Kalaleh & 117,319 & 97.9 & 8.5 \\
Kordkouy & 71,270 & 100.0 & - \\
Maraveh Tappeh & 60,953 & 96.8 & - \\
Minoudasht & 75,483 & 94.5 & - \\
Ramian & 86,210 & 98.4 & \\
\hline
\end{tabular}

\subsubsection{Capacity}

Regarding literacy rate, no significant differences exist between the districts (Table 5). Gorgan, as the capital district, and Maraveh Tappeh had respectively the highest (90.6\%) and lowest (83.5\%) levels of literacy rates. However, a major deviation emerges when considering access to health centers. Maraveh Tappeh, Minudasht, Gomishan, Galikesh, Bandar Gaz, and Bandar Turkmen have the fewest health centers in Golestan Province and require more attention from the corresponding authorities. As for the access to electricity (electrification rate), except for Gonbade Kavus (96.7\%), Gorgan (92.7\%) and Kordkouy (92.7\%), the rest of the districts have low to moderate access ratios, with Maraveh Tappeh having the lowest rate of electrification $(46.7 \%)$. With respect to the proportion of the population receiving remittance, pension, and wages, all districts obtained extremely low values implying the low capacity of the population especially the poor communities to deal with water scarcity and improve water management.

Table 5. The status of the "Capacity" component in different districts of Golestan Province.

\begin{tabular}{ccccc}
\hline Districts & $\begin{array}{c}\text { Literacy Rate } \\
(\mathbf{\%}) \mathbf{( \mathbf { C } _ { \mathbf { 1 } } )}\end{array}$ & $\begin{array}{c}\text { Number of Health } \\
\text { Centers }\left(\mathbf{C}_{\mathbf{2}} \mathbf{)}\right.\end{array}$ & $\begin{array}{c}\text { Access to } \\
\text { Electricity } \mathbf{( \% )}\left(\mathbf{C}_{\mathbf{3}}\right)\end{array}$ & $\begin{array}{c}\text { Households Receiving } \\
\text { Funds } \mathbf{( \% )}\left(\mathbf{C}_{\mathbf{4}}\right)\end{array}$ \\
\hline Aliabad & 88.0 & 22 & 72.0 & 16.1 \\
Aq Qala & 84.7 & 13 & 73.0 & 11.0 \\
Azadshahr & 87.8 & 11 & 70.6 & 15.5 \\
Bandar Gaz & 91.6 & 7 & 81.1 & 16.9 \\
Bandar Turkmen & 86.0 & 7 & 70.8 & 11.0 \\
Galikesh & 87.5 & 8 & 69.3 & 15.7 \\
Gomishan & 84.8 & 7 & 58.1 & 9.3 \\
Gonbade Kavus & 86.5 & 33 & 96.7 & 11.6 \\
Gorgan & 90.6 & 57 & 92.7 & 9.4 \\
Kalaleh & 85.8 & 14 & 69.7 & 14.4 \\
Kordkouy & 91.4 & 10 & 92.7 & 22.8 \\
Maraveh Tappeh & 83.5 & 6 & 46.7 & 13.8 \\
Minoudasht & 88.4 & 7 & 74.2 & 19.1 \\
Ramian & 87.2 & 10 & 66.1 & 19.4 \\
\hline
\end{tabular}

\subsubsection{Use}

Table 6 provides the summary of the results obtained for the "Use" component of WPI index. With respect to domestic water use Gorgan, Gonbad Kavus, Aliabad, and Aq Qala districts have the highest consumption levels, which is also indicated by their higher populations. As for livestock water consumption, Gonbad Kavus, Maraveh Tappeh, Gorgan and Aq Qala have significantly greater water consumptions. Industrial water use is highest in Gorgan and lowest in Ramian, Kalaleh, and Galikesh. These districts are in fact the least industrially active areas in Golestan Province. As in the case of 
agricultural water use which was calculated based on the ratio between the area of the irrigated agricultural lands to rain-fed agricultural lands, Gorgan obtained the highest value. Apparently, the agricultural water use ratio decreases in drier districts such as Gomishan, Maraveh Tappeh and Aq Qala, Gonbad Kavus and Bandar Turkmen. Minoudasht is an interesting case having most of its agricultural lands used as rain-fed agriculture while having diverse water sources and high precipitation unreliability (69\% precipitation CV). This district is comparatively less populated while having high domestic water use. It appears that water use can be significantly improved in this province by improving domestic water consumption, agricultural activities and improving the industrial use of water. Based on the results, water use is highest in Gorgan District and lowest in Bandar Turkmen.

Table 6. The status of the "Use" component in different districts of Golestan Province.

\begin{tabular}{ccccc}
\hline \multirow{2}{*}{ Districts } & \multicolumn{3}{c}{ Water Use $\left(\times \mathbf{1 0}^{\mathbf{3}} \mathbf{~ m}^{\mathbf{3}}\right)$} & \multirow{2}{*}{ Agricultural Water Use $\mathbf{( U}_{\mathbf{3}} \mathbf{)}$} \\
\cline { 2 - 4 } & Domestic $\left(\mathbf{U}_{\mathbf{1}}\right)$ & Livestock $\left(\mathbf{U}_{\mathbf{2}}\right)$ & Industrial $\left(\mathbf{U}_{\mathbf{4}}\right)$ & \\
Aliabad & 3289.0 & 657.1 & 145.0 & 0.2 \\
Aq Qala & 3792.6 & 1186.4 & 217.0 & 0.8 \\
Azadshahr & 1603.9 & 694.8 & 112.0 & 0.6 \\
Bandar Gaz & 1505.2 & 385.7 & 39.0 & 0.3 \\
Bandar Turkmen & 876.6 & 259.7 & 473.0 & 0.7 \\
Galikesh & 1669.3 & 304.8 & 19.0 & 0.0 \\
Gomishan & 2115.4 & 949.0 & 160.0 & 0.4 \\
Gonbade Kavus & 5163.2 & 3537.1 & 167.0 & 3.5 \\
Gorgan & 6321.2 & 1611.9 & 2688.0 & 2.2 \\
Kalaleh & 2595.0 & 1203.9 & 24.0 & 0.7 \\
Kordkouy & 2194.1 & 311.1 & 189.0 & 0.1 \\
Maraveh Tappeh & 1146.2 & 2030.0 & 28.0 & 0.2 \\
Minoudasht & 1875.5 & 828.9 & 266.0 & 2.3 \\
Ramian & 2387.0 & 551.8 & 14.0 & \\
\hline
\end{tabular}

\subsubsection{Environment}

The score that each district obtained on flooding, erosion, and desertification are provided in Table 7. The "Environment" component was evaluated based on the severity of desertification, erosion, and flooding that can adversely affect availability, access, and use of water resources. Almost all districts are encountering some levels of desertification, but it is more pronounced in Gomishan (4.1), Gonbad Kavus (3.6), Aq Qala (3.5), and Maraveh Tappeh (3.0) as the northern districts of Golestan Province near Qarah Qom Desert of Turkmenistan. The southern districts, such as Gorgan, Aliabad, and Kordkouy have dense forest and rangeland vegetation cover and ambient precipitation which protect these districts from severe desertification. Erosion is mostly in the form of water erosion in the southern districts of the province while shifting into wind erosion in drier districts to the north and north-eastern parts of the province. Both wind and water erosion are active in the middle of the province such as the northern parts of Azadshahr, Kalaleh, Minoudasht and Ramian districts as well as the southern parts of Maraveh Tappeh, Gonbad Kavus, Aq Qala and Gomishan districts. However, the mid-range of the province such as Minoudasht, Galikesh, and Gomishan are at risk of flooding. The risk of flash floods is more pronounced in Gonbad Kavus (4.5), Maraveh Tappeh (4.4), Aliabad (4.3), and Azadshahr (4.1) districts. Golestan Province climate is characterized by heavy summer rain showers. The occurrence of rain showers coincides with the lowest level of soil moisture and vegetation cover in the middle to the north-eastern part of the province which results in a high probability of flash floods in these areas. 
Table 7. The status of the "Environment" component in different districts of Golestan Province.

\begin{tabular}{cccc}
\hline District & Risk of Desertification $\left(\mathbf{E}_{\mathbf{1}}\right)$ & Risk of Erosion $\left(\mathbf{E}_{\mathbf{2}}\right)$ & Risk of Flooding $\left(\mathbf{E}_{\mathbf{3}}\right)$ \\
\hline Aliabad & 1.0 & 2.3 & 4.3 \\
Aq Qala & 3.5 & 1.1 & 2.0 \\
Azadshahr & 1.0 & 2.8 & 4.1 \\
Bandar Gaz & 1.0 & 1.6 & 1.1 \\
Bandar Turkmen & 1.0 & 1.0 & 1.4 \\
Galikesh & 1.0 & 2.8 & 1.0 \\
Gomishan & 4.1 & 1.0 & 1.0 \\
Gonbade Kavus & 3.6 & 2.4 & 4.5 \\
Gorgan & 1.0 & 2.4 & 2.3 \\
Kalaleh & 2.3 & 2.8 & 3.2 \\
Kordkouy & 1.0 & 2.1 & 2.3 \\
Maraveh Tappeh & 3.0 & 3.3 & 4.4 \\
Minoudasht & 1.0 & 2.9 & 1.0 \\
Ramian & 1.0 & 2.4 & 1.0 \\
\hline
\end{tabular}

\subsection{WPI Aggregation}

The results of the normalized scores obtained for each WPI subcomponent along with the magnitude of WPI in each district are illustrated in Figure 4. Please note that equal weights were assigned to the components and the subcomponents of the WPI index. Lawrence et al. [31] have classified WPI as severe (WPI <48), high (48-56), medium (56-62), medium-low (62-68) and low (WPI $>68$ ). According to this classification, WPI 62 has been indicated to be the threshold between the low and medium water poverty severity. The overall water poverty level of the Golestan Province was evaluated to be 41.1, indicating a severe water poverty for the study area. Based on this finding, Golestan Province is lagging far beyond a sustainable water management condition. However, except for Gorgan which is very close to the threshold (i.e., 61.6), all districts have a severe water poverty condition, among which the districts Azadshahr (29.1), Galikesh (31.6) and Maraveh Tappeh (32.7) had the worst conditions. Figure 5 illustrates the differences in WPI components in Azadshahr and Gorgan districts, as the two lower and upper extremes of the WPI range, respectively. 


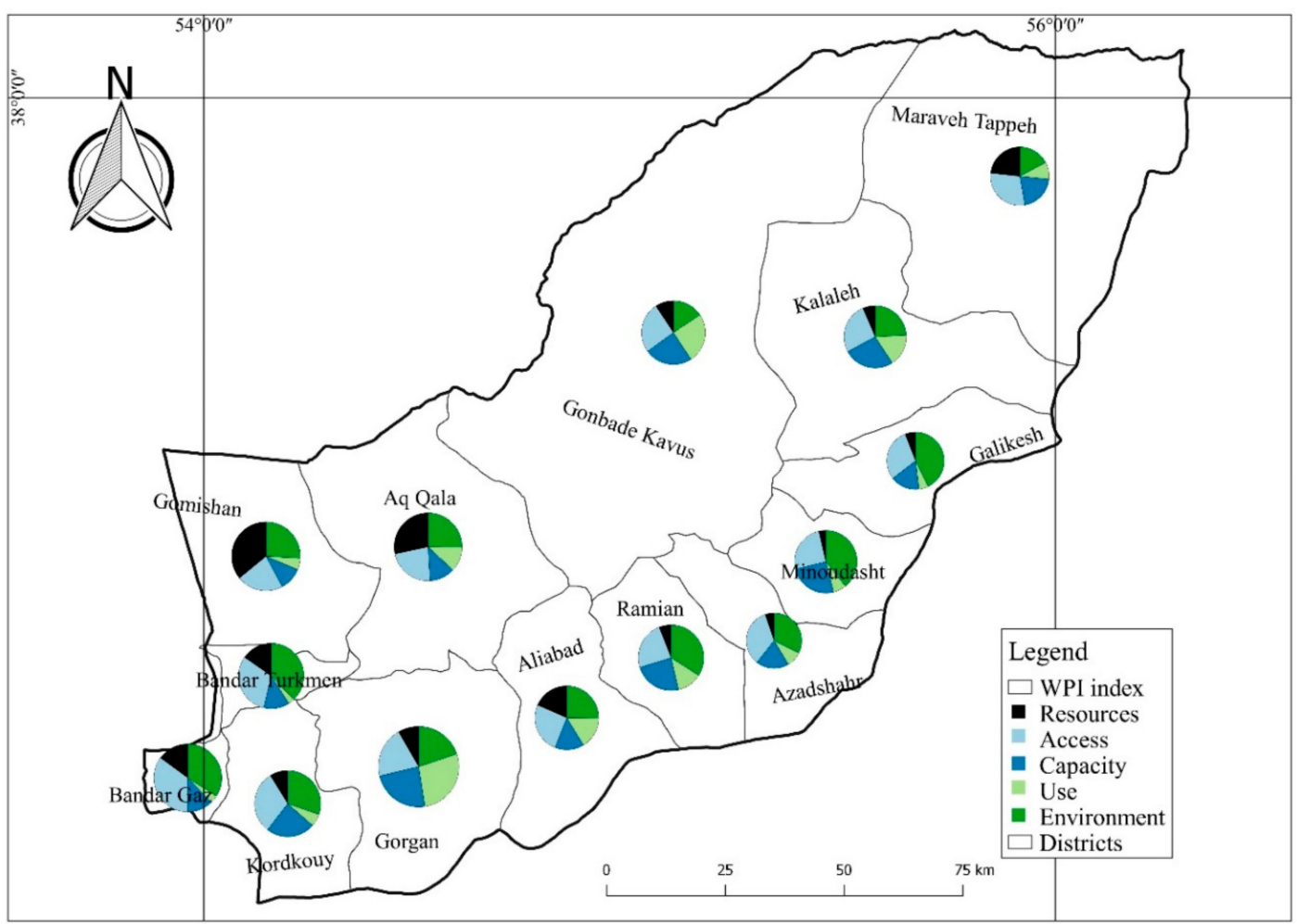

Figure 4. Spatial differences of WPI index component scores in the districts of Golestan Province, Iran.

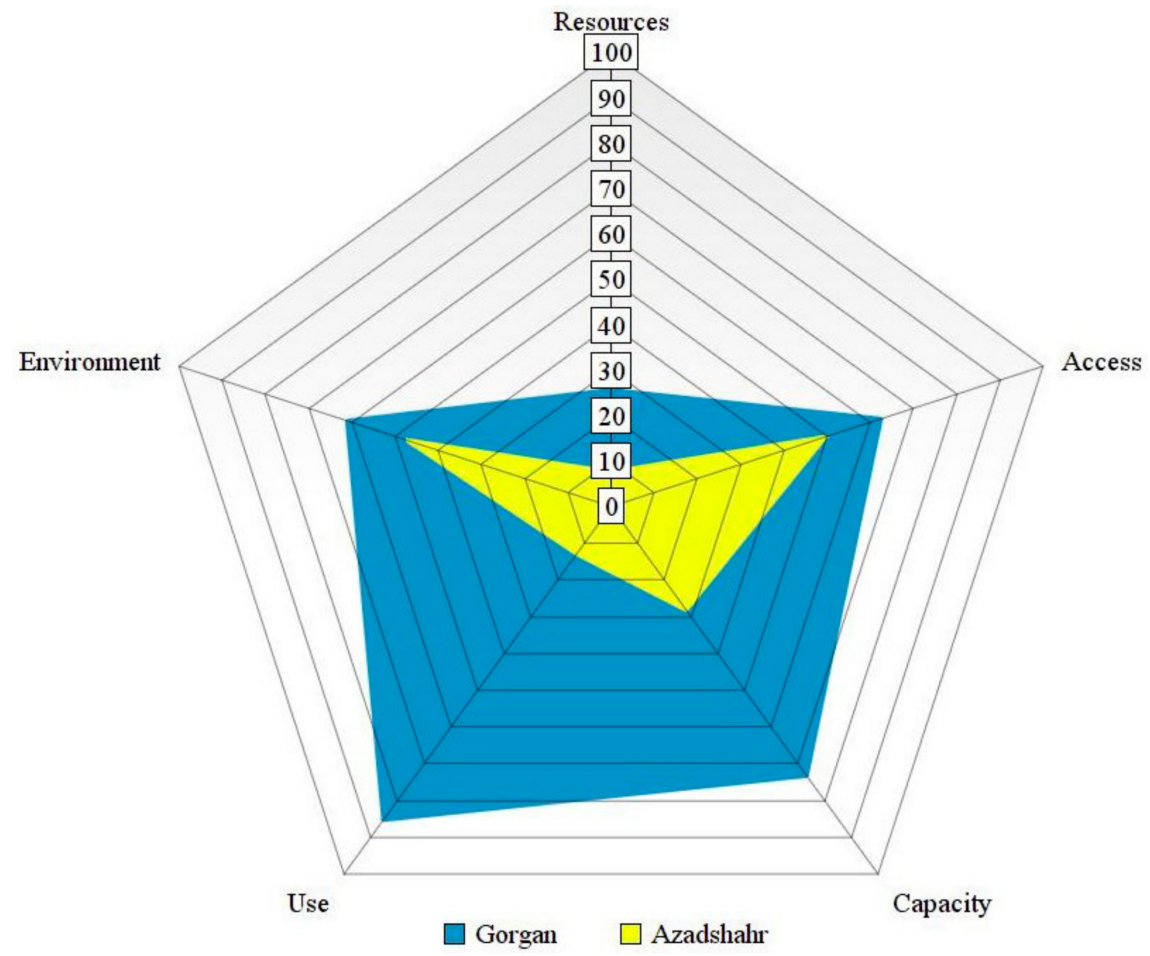

Figure 5. The radar chart showing the score of different water poverty index components in the districts of Azadshahr (yellow) and Gorgan (blue) representing the districts with the worst and the best conditions, respectively. 


\subsection{Sensitivity Analysis}

As also illustrated in Figure 3, except for Aliabad, Aq Qala, Gomishan, and Maraveh Tappeh all districts have physical water scarcity in Golestan Province. Given that the physical quantity of water cannot be directly altered, only the weights of "Access", "Capacity", "Use" and "Environment" components were altered. By putting emphasis on the "Access", "Capacity" and "Use" components, WPI score rose in Gonbad Kavus, Gorgan, and Kalaleh, while significantly decreased in all other districts. It implies that except for these three districts, improving access to water sources, capacity to manage water, as well as water consumption could result in a major improvement in WPI in other areas. In the next step, a higher weight was assigned to the "Use" component. Results indicated a major reduction in WPI score in all districts except for Gonbad Kavus and Gorgan. By stressing on the importance of the "Access" and "Capacity" in the third alternative, the situation slightly improved in Gonbad Kavus and Maraveh Tappeh. Finally, a higher importance was assigned to the "Access", "Capacity" and "Environment" components. By doing so, the overall WPI score rose in Aq Qala and Bandar Gaz, while decreased in the rest of the cases. In general, changing the importance of different components did not improve WPI. This is mainly due to the low scores obtained on WPI components in the districts of Golestan Province. Although the total amount of physical water quantity is constant, there is a big potential to improve water scarcity in this province by enhancing other components of WPI index. The correlation between different components of WPI was also evaluated using the Pearson correlation method, and the results are provided in Table 8. There was a significant correlation between the "Use" and the "Capacity" component $(0.75, p$-value $<0.05)$. Therefore, it can be suggested that "Capacity" and "Use" can affect each other significantly. For example, any improvement in using water for economic purposes could result in better capacity and vice versa. We repeated the calculations by leaving out the "Capacity" component, but it resulted in an 8.1-unit reduction in WPI. By removing the capacity component, the WPI status in the northern districts of Gomishan and Aq Qala improved while worsened in most of the eastern districts. This indicates that emphasis must be put on improving capacity in the northern districts while improving other components in the eastern areas. The results of incorporating different weighting schemes along with leaving out the "Capacity" component are illustrated in Figure 6A-F.

Table 8. Correlation between different components of WPI.

\begin{tabular}{cccccr}
\hline WPI Components & Resources & Access & Capacity & Use & Environment \\
\hline Access & $0.04(0.89)$ & & & \\
Capacity & $-0.42(0.13)$ & $0.10(0.72)$ & & \\
Use & $-0.06(0.82)$ & $0.01(0.96)$ & $0.075(0.00)$ & & \\
Environment & $-0.07(0.79)$ & $0.46(0.09)$ & $-0.04(0.88)$ & $-0.29(0.31)$ & \\
WPI & $0.34(0.22)$ & $0.48(0.07)$ & $0.55(0.03)$ & $0.67(0.00)$ & $0.29(0.31)$ \\
\hline \multicolumn{6}{c}{ Cell Contents: Pearson correlation $(p$-Value). }
\end{tabular}




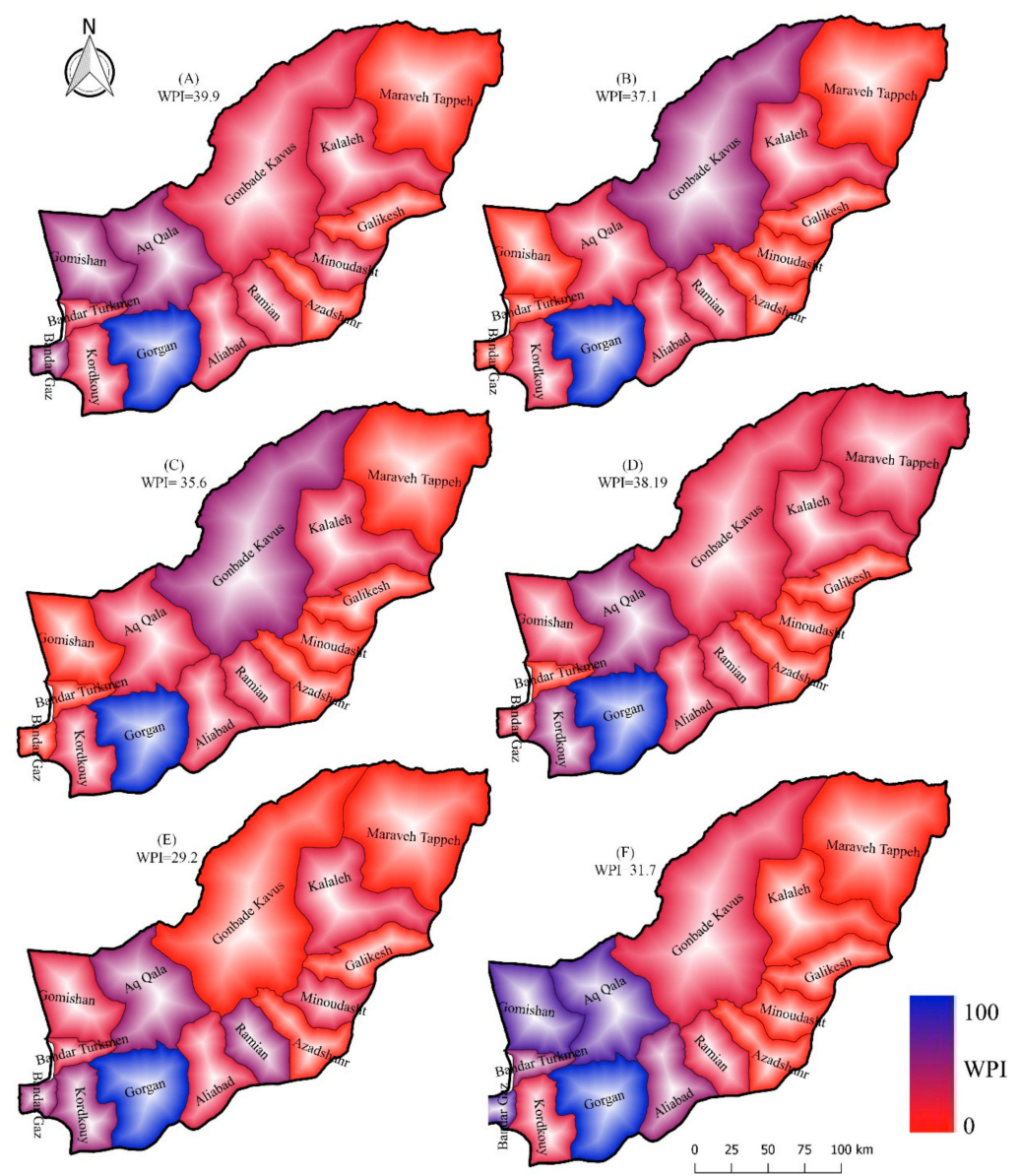

Figure 6. Using different weigh assigning schemes for the calculation of WPI: (A): baseline, (B): alternative 1, (C): alternative 2, (D): alternative 3, (E): alternative 4, (F) leaving out "Capacity" component.

\section{Discussion}

In this research, water scarcity was evaluated from a different view incorporating both physical shortage and socio-economic factors. Components such as water supply, sanitation, access, use and environmental condition have been combined to better picture the reality of water scarcity [36]. Using only physical availability of water as the indicator cannot clearly indicate water stress, as Gomishan District having the highest per-capita water availability had a low WPI value. Although WPI has been extensively used in the literature and it involves the most important dimensions of water availability, it does not explicitly state how to approach physical availability of water [54]. Unconventional water sources have also not been envisaged in this indicator. Sullivan et al. [55] believe that non-conventional sources such as vapor streams should be included when estimating water poverty. This is especially the case in Golestan Province where the Caspian Sea supplies most of the precipitation and air moisture. Moreover, some villages in Maraveh Tappeh and Gonbad Kavus districts use domestic rainwater harvesting systems to store water for the summer period when water supply form the central network has interruptions (even up to a month).

Access to water was evaluated from two sub-indicators of access to improved sanitation and access to water supply network $[48,52,55]$. Our results indicated that almost all districts have enough access to water supply network. However, assessing the "Access" component only based on the level of access to the network is not enough, as many of the rural areas of the northern part of the province experience long periods without water, when water is provided to them by water tankers trucks. On the other hand, long cessation of water supply can result in the deterioration of water quality when reconnected. Remaining water reacts with the pipe material and also create biofilm and tubercles on the pipe wall 
which can enter the water current the next time water is connected [56]. However, as data is not available on this component, we only evaluated the level of access. As for the access to improved sanitation, the proportion of the population connected to the main sewer collection network and treatment plants was used. Most of the population have enough access to basic sanitation services such as bathing and water closet. However, only a small proportion of the houses are connected to a sewage collection network. This leads to two important consequences. The first one is the deterioration of surface and groundwater sources as the result of the release of untreated sewer, which can then lower the volume of the available water. The second is the loss of a potential water source which otherwise could replace the drinking water used for everyday urban and domestic consumption. Currently, only Bandar Gaz, Bandar Turkmen, Gorgan, and Kordkouy are connected to the network. This must be one of the top priorities for water managers.

Regarding the "Capacity" component, the literacy rate of all districts seems satisfactory. Literacy rate cannot only help better manage the already scarce water resources, but it can affect directly other components. Esrey and Habicht [57] found that infant mortality rate decreased from 130 deaths in the absence of literate mothers to 76.2 in the presence of literate mothers. Van Ty et al. [53] also found that a low rate of literacy can increase water poverty. As for the primary medical services centers, Aliabad, Bandar Turkmen and Kalaleh had the lowest scores. This factor can directly affect water poverty by reducing infant mortality rate [53]. On the other hand, water is stored by some villagers in the northern rural areas of the province, during the summer period. The responsibility for disinfecting these water storages is with the local medical services. Therefore, lack of access to these centers can result in the spread of water-borne vectors and diseases, higher mortality rate, migration of people and further social issues. Access to electricity is also another important factor for social and economic development. Gomishan, Galikesh, Bandar Turkmen and Bandar Gaz districts had the lowest level of access to electricity which can negatively affect its economic development and water management status. The importance of access to electricity has also been emphasized by Hamouda et al. [58] and Komnenic et al. [54]. Therefore, improvement of access to electricity could be one of the priorities in these districts for boosting economic development and reducing both poverty and water-related poverty. In all districts, the amount of income from remittance, pension, and wages is quite low. Raising household income through different paths could result in poverty reduction and better management of water resources. For instance, Hanjra et al. [59] found that investing the extra money in irrigation programs could result in better management of water resources and poverty eradication. In another case, Renwick and Archibald [60] argued that receiving funds in the form of subsidies can enhance the adoption of water-efficient technologies and hence better water management.

Water use in different districts of the province was evaluated based on domestic, livestock, agricultural and industrial water consumption. All these consumptions are supposed to help the economic development of the area. However, most of the water is being used with quite low performance in these sectors, and hence cannot be solely regarded as the proxy for economic development. The intensity of use is more pronounced in Gorgan (for domestic, agricultural, and industrial purposes) and in Gonbad Kavus (for livestock production). Similar findings have been reported by Van Ty et al. [53], who found "Use" and "Capacity" as the most important components of WPI in a case study in Vietnam and Cambodia. We believe that enhancing water use should be the priority in Gorgan District.

In terms of "Environment", the severity of desertification, erosion and flooding were considered as three proxies. Accordingly, most districts of the province face high levels of desertification, which can result in decreasing level of water availability in both quantity and quality terms. During the recent decades, vast expanses of forest lands in the southern part of the province have been clear-cut for transient agriculture which has resulted in an increased risk of desertification, erosion, and flooding [61]. Akbari et al. [62] proposed the following strategies for coping with desertification and water-related issues in Golestan Province including revegetation, improvement of drainage networks, and building resilient water infrastructure. Elsewhere, Akbari et al. [63] propose the development of an early 
warning system for monitoring desertification and erosion which could be used along with our aim of improved water management and use.

Finally, we used the weighted multiplicative function for data aggregation and calculating WPI from its five components [37]. Firstly, we assigned equal weights to WPI components. Sullivan et al. [49] believe that although different weighting schemes could be rational for WPI components, equal indicator weights are preferred. The additive aggregation techniques which were used in recent literature regarding WPI, allows for full compensability between different components, meaning that low score on one factor could be compensated by high values on others [64]. However, weights have to be used as "non-compensatory" if they are to be taken as the proxies of importance [37]. Yet, we evaluated the possibility of using different weights to see how WPI value changes in response to improving one or more than one component. However, none of the alternatives resulted in higher WPI values. We also evaluated the correlation between different WPI components and found a significant relationship between Access and Capacity. By removing "Capacity" from the main dataset, there was a sharp reduction in WPI value. Our result is inconsistent with those of Van Ty et al. [53], which found a major improvement in WPI by leaving out "Capacity", "Use" and "Access" in the analysis. They believe that lack of access to water services may be due to the lack of income or education. Finally, the highest correlation between WPI and its subcomponents were found for the "Access", "Capacity", and "Use". Therefore, any attempt to improve water poverty in the province must primarily be aligned with these three components.

\section{Conclusions}

In this paper, we used the WPI to evaluate the status of water scarcity in Golestan Province of Iran. The items listed under WPI components were identified in close collaboration with the experts and scientific community working in the field of water management in this province. The WPI proved to be a suitable measure of water scarcity in Golestan Province, and the results could be used for further policy-making and prioritizations. Based on our analysis, the overall WPI of the province was evaluated to be 41.1 which indicates a severe level of water scarcity. Among 14 districts studied, Gorgan (61.6) obtained the highest WPI score. This district, however, faces water availability and variability issue by obtaining 25.7 in terms of "Resources" component. Improving water use efficiency and using unconventional water sources (rainwater harvesting for domestic and urban use purposes, treatment and utilization of municipal sewage, and desalinization of seawater preferably by using renewable energies) could improve water availability in not only Gorgan District, but all other areas of Golestan Province. The lowest scores of WPI were obtained in Azadshahr (29.1), Galikesh (31.6), and Maraveh Tapeh (32.7) districts, which must be the top priorities for water managers in Golestan Province. We recommend that each case be evaluated based on its components and not on the overall WPI score. Accordingly, in Azadshahr and Galikesh, the priority is to improve water use and capacity components. In Maraveh Tappeh, improving the "Environment" component by better land-use management (to prevent desertification), wastewater and sewage treatment (which otherwise is released to the waterways and pollute the environment and water sources), and protection against floods and erosion should be the top priorities. Based on our findings, WPI is most sensitive to access, capacity and use components. As for the use component, establishing and developing sewage treatment plants are the top priorities in all districts of Golestan Province. We also found that capacity and use have the highest correlation with WPI. Therefore, improving access (by enhancing literacy rate, electrification rate, income) can significantly improve WPI. On the other hand, using water efficiently for economic growth in Golestan Province can improve the access component and the overall water poverty status. The results of this research are being discussed with water managers in Golestan Provincem, for future policy makings and prioritizations.

Author Contributions: The first author was in charge of research conceptualization, data curation, software analysis, methodology and writing the original draft of the paper. The second author supervised the work, acquired funding, helped in methodology development, editing and submission of the paper. 
Funding: The work was supported by the National Key R\&D Program of China under Grant No. 2016YFA0602302 and No. 2016YFB0502502.

Acknowledgments: The LULC data set is provided by the Data Center for Resources and Environmental Sciences, Chinese Academy of Sciences (RESDC) (http://www.resdc.cn). The GLDAS data used in this study were acquired as part of the mission of NASA's Earth Science Division and archived and distributed by the Goddard Earth Sciences (GES) Data and Information Services Center (DISC). We would like to appreciate the CAS-TWAS fellowship program.

Conflicts of Interest: The authors declare no conflict of interest.

\section{References}

1. Oki, T.; Kanae, S. Global hydrological cycles and world water resources. Science 2006, 313, $1068-1072$. [CrossRef] [PubMed]

2. Pisani, E. The Management of Water as an Essential and Rare Commodity. Water Int. 1995, 20, $29-31$. [CrossRef]

3. Rijsberman, F.R. Water scarcity: Fact or fiction? Agric. Water Manag. 2006, 80, 5-22. [CrossRef]

4. Biswas, A.K. Water for sustainable development in the 21st century: A global perspective. Int. J. Water Resour. Dev. 1991, 7, 219-224. [CrossRef]

5. Vörösmarty, C.J.; Green, P.; Salisbury, J.; Lammers, R.B. Global water resources: Vulnerability from climate change and population growth. Science 2000, 289, 284-288. [CrossRef] [PubMed]

6. Abu-Zeid, M.A. Water and sustainable development: The vision for world water, life and the environment1. This paper is based on a keynote address made at the International Conference on Water and Sustainable Development, Paris, 19 March 1998. Water Policy 1998, 1, 9-19. [CrossRef]

7. Kim, J.H.; Keane, T.D.; Bernard, E.A. Fragmented local governance and water resource management outcomes. J. Environ. Manag. 2015, 150, 378-386. [CrossRef] [PubMed]

8. Döll, P.; Trautmann, T.; Gerten, D.; Schmied, H.M.; Ostberg, S.; Saaed, F.; Schleussner, C.F. Risks for the global freshwater system at $1.5^{\circ} \mathrm{C}$ and $2{ }^{\circ} \mathrm{C}$ global warming. Environ. Res. Lett. 2018, 13, 44038. [CrossRef]

9. Gleick, P.H. Water and conflict: Fresh water resources and international security. Int. Secur. 1993, 18, 79-112. [CrossRef]

10. Lonergan, S.C. Water and conflict: Rhetoric and reality. In Environmental Conflict; Routledge: Abingdon, UK, 2018; pp. 109-124. ISBN 978-0230289185.

11. Wolf, A.T. waterways. In Environmental Change, Adaptation, and Security; Springer: Dordrecht, The Netherlands, 1999; pp. 251-265. ISBN 978-94-010-5832-2.

12. De Stefano, L.; Petersen-Perlman, J.D.; Sproles, E.A.; Eynard, J.; Wolf, A.T. Assessment of transboundary river basins for potential hydro-political tensions. Glob. Environ. Chang. 2017, 45, 35-46. [CrossRef]

13. Feitelson, E.; Tubi, A. A main driver or an intermediate variable? Climate change, water and security in the Middle East. Glob. Environ. Chang. 2017, 44, 39-48. [CrossRef]

14. Feitelson, E.; Chenoweth, J. Water poverty: Towards a meaningful indicator. Water Policy 2002, 4, $263-281$. [CrossRef]

15. Brown, A.; Matlock, M.D. A review of water scarcity indices and methodologies. White Pap. 2011, 106, 1-19.

16. Falkenmark, M. The Massive Water Scarcity Now Threatening Africa: Why Isn't It Being Addressed? Ambio 1989, 18, 112-118. [CrossRef]

17. Ohlsson, L.; Appelgren, B. Water and Social Resource Scarcity; FAO (Food and Agricultural Organization) Issue Paper; FAO: Rome, Italy, 1998.

18. Yang, H.; Reichert, P.; Abbaspour, K.C.; Zehnder, A.J.B. A water resources threshold and its implications for food security. Environ. Sci. Technol. 2003, 37, 3048-3054. [CrossRef] [PubMed]

19. Raskin, P.; Gleick, P.; Kirshen, P.; Pontius, G.; Strzepek, K. Water Futures: Assessment of Long-Range Patterns and Problems. Comprehensive Assessment of the Freshwater Resources of the World; SEI: Boston, MA, USA, 1997.

20. Chaves, H.M.L.; Alipaz, S. An integrated indicator based on basin hydrology, environment, life, and policy: The watershed sustainability index. Water Resour. Manag. 2007, 21, 883-895. [CrossRef]

21. McNulty, S.G.; Sun, G.; Myers, J.A.M.; Cohen, E.C.; Caldwell, P. Robbing Peter to pay Paul: Tradeoffs between ecosystem carbon sequestration and water yield. In Proceedings of the Environmental Water Resources Institute Meeting, Madison, WI, USA, 23-27 August 2010; pp. 103-114. 
22. Asheesh, M. Allocating gaps of shared wáter resources (scarcity index): Case study on Palestine-Israel. In Water Resources in the Middle East; Springer: Heidelberg, Germany, 2007; pp. 241-248. ISBN 978-3-540-69508-0.

23. Smakthin, V.; Revenga, C.; Doll, P. Taking into Account Environmental Water Requirements; International Water Management Institute (IWMI), Comprehensive Assessment Secretariat: Colombo, Sri Lanka, 2004.

24. Pfister, S.; Koehler, A.; Hellweg, S. Assessing the Environmental Impacts of Freshwater Consumption in LCA. Environ. Sci. Technol. 2009, 43, 4098-4104. [CrossRef] [PubMed]

25. Savenije, H.H.G. Water scarcity indicators; the deception of the numbers. Phys. Chem. Earth Part B 2000, 25, $199-204$. [CrossRef]

26. Ye, Q.; Li, Y.; Zhuo, L.; Zhang, W.; Xiong, W.; Wang, C.; Wang, P. Optimal allocation of physical water resources integrated with virtual water trade in water scarce regions: A case study for Beijing, China. Water Res. 2018, 129, 264-276. [CrossRef] [PubMed]

27. Chapagain, A.K.; Hoekstra, A.Y. The global component of freshwater demand and supply: An assessment of virtual water flows between nations as a result of trade in agricultural and industrial products. Water Int. 2008, 33, 19-32. [CrossRef]

28. McCaffrey, S.C. A human right to water: Domestic and international implications. Geo. Int. Envtl. L. Rev. $1992,5,1$.

29. Pietrucha-Urbanik, K. Assessing the Costs of Losses Incurred as a Result of Failure BT-Dependability Engineering and Complex Systems; Springer International Publishing: Wrocław, Poland, 2016; pp. 355-362.

30. Pietrucha-Urbanik, K.; Żelazko, A. Approaches to Assess Water Distribution Failure. Period. Polytech. Civ. Eng. 2017, 61. [CrossRef]

31. Lawrence, P.R.; Meigh, J.; Sullivan, C. The water poverty index: An international comparison. Nat. Resour. Forum 2003, 27, 189-199. [CrossRef]

32. Ohlsson, L.; Turton, A.R. The Turning of a Screw: Social Resource Scarcity as a Bottle-Neck in Adaptation to Water Scarcity; School of Oriental and African Studies Water Study Group, University of London: London, UK, 1999.

33. Gallopín, G.C. Linkages between vulnerability, resilience, and adaptive capacity. Glob. Environ. Chang. 2006, 16, 293-303. [CrossRef]

34. Oh Isson, L. Water conflicts and social resource scarcity. Phys. Chem. Earth Part B 2000, 25, 213-220. [CrossRef]

35. Salameh, E. Redefining the water poverty index. Water Int. 2000, 25, 469-473. [CrossRef]

36. Sullivan, C.A.; Meigh, J.R.; Simon, S.; Lawrence, P.; Calow, R.C.; Mckenzie, A.A.; Acreman, M.C.; Moore, R.V. The Development of a Water Poverty Index: A Feasibility Study; Centre for Ecology and Hydrology/Department for International Development: Wallingford, UK, 2000.

37. Garriga, R.G.; Foguet, A.P. Improved method to calculate a water poverty index at local scale. J. Environ. Eng. 2010, 136, 1287-1298. [CrossRef]

38. Pérez-Foguet, A.; Giné Garriga, R. Analyzing Water Poverty in Basins. Water Resour. Manag. 2011, $25,3595$. [CrossRef]

39. Molle, F.; Mollinga, P. Water poverty indicators: Conceptual problems and policy issues. Water Policy 2003, 5, 529-544. [CrossRef]

40. Sullivan, C.A.; Meigh, J. Integration of the biophysical and social sciences using an indicator approach: Addressing water problems at different scales. Water Resour. Manag. 2007, 21, 111-128. [CrossRef]

41. Shirdeli, A. Evaluation of the water resources sustainability in Iran and Ghareghom watershed by international indices in 1404 vision. Water Manag. Arid Lands 2014, 1, 53-61.

42. Golestan Province Governorship. Territorial Planning of Golestan Provine, Iran; Golestan Province Governorship Publication: Gorgan, Iran, 2016.

43. Jafari Shalamzari, M.; Sheikh, V.B.; Sadoddin, A.; Abedi Sarvestani, A. Public Perception and Acceptability toward Domestic Rainwater Harvesting in Golestan, Limits to Up-Scaling. Ecopersia 2016, 4, 1437-1454. [CrossRef]

44. Zehtabian, G.; Khosravi, H.; Ghodsi, M. High Demand in a Land of Water Scarcity: Iran BT-Water and Sustainability in Arid Regions: Bridging the Gap between Physical and Social Sciences; Springer: Dordrecht, The Netherlands, 2010; pp. 75-86. ISBN 978-90-481-2776-4.

45. Madani, K. Water management in Iran: What is causing the looming crisis? J. Environ. Stud. Sci. 2014, 4, 315-328. [CrossRef]

46. Ardakanian, R. Overview of water management in Iran. In Water Conservation, Reuse, and Recycling, Proceeding of an Iranian American Workshop; The National Academies Press: Washington, DC, USA, 2005; pp. 153-172.

47. Sullivan, C. Calculating a water poverty index. World Dev. 2002, 30, 1195-1210. [CrossRef] 
48. Faraj Zadeh, M.; Servati, M.R.; Taheri, V. Analysis and zonation of geomorpholocal hazards in Golestan Province. Quaterly J. Nat. Geogr. 2011, 4, 45-62.

49. Sullivan, C.A.; Meigh, J.R.; Giacomello, A.M. The Water Poverty Index: Development and application at the community scale. Nat. Resour. Forum 2003, 27, 189-199. [CrossRef]

50. Choramin, M.; Safaei, A.; Khajavi, S.; Hamid, H.; Abozari, S. Analyzing and studding chemical water quality parameters and its changes on the base of Schuler, Wilcox and Piper diagrams (project: Bahamanshir River). WALIA J. 2015, 31, 22-27.

51. Manandhar, S.; Pandey, V.P.; Kazama, F. Application of water poverty index (WPI) in Nepalese context: A case study of Kali Gandaki River Basin (KGRB). Water Resour. Manag. 2012, 26, 89-107. [CrossRef]

52. Babel, M.S.; Wahid, S.M. Freshwater under Threat South Asia: Vulnerability Assessment of Freshwater Resources to Environmental Change: Ganges-Brahmaputra-Meghna River Basin, Helmand River Basin, Indus River Basin; UNEP (United Nations Environment Programme): Nairobi, Kenya, 2009; ISBN 9280729497.

53. Van Ty, T.; Sunada, K.; Ichikawa, Y.; Oishi, S. Evaluation of the state of water resources using Modified Water Poverty Index: A case study in the Srepok River basin, Vietnam-Cambodia. Int. J. River Basin Manag. 2010, 8, 305-317. [CrossRef]

54. Komnenic, V.; Ahlers, R.; Van Der Zaag, P. Assessing the usefulness of the water poverty index by applying it to a special case: Can one be water poor with high levels of access? Phys. Chem. Earth Parts A/B C 2009, 34, $219-224$. [CrossRef]

55. Sullivan, C.; Meigh, J.; Lawrence, P. Application of the Water Poverty Index at different scales: A cautionary tale. Water Int. 2006, 31, 412-426. [CrossRef]

56. Al-Jasser, A.O. Chlorine decay in drinking-water transmission and distribution systems: Pipe service age effect. Water Res. 2007, 41, 387-396. [CrossRef] [PubMed]

57. Esrey, S.A.; Habicht, J.-P. Maternal literacy modifies the effect of toilets and piped water on infant survival in Malaysia. Am. J. Epidemiol. 1988, 127, 1079-1087. [CrossRef] [PubMed]

58. Hamouda, M.A.; El-Din, M.M.N.; Moursy, F.I. Vulnerability assessment of water resources systems in the Eastern Nile Basin. Water Resour. Manag. 2009, 23, 2697-2725. [CrossRef]

59. Hanjra, M.A.; Ferede, T.; Gutta, D.G. Pathways to breaking the poverty trap in Ethiopia: Investments in agricultural water, education, and markets. Agric. Water Manag. 2009, 96, 1596-1604. [CrossRef]

60. Renwick, M.E.; Archibald, S.O. Demand side management policies for residential water use: Who bears the conservation burden? Land Econ. 1998, 343-359. [CrossRef]

61. Abad, J.R.S.; Khosravi, H.; Alamdarlou, E.H. Assessment the effects of land use changes on soil physicochemical properties in Jafarabad of Golestan province, Iran. Bull. Environ. Pharmacol. Life Sci. 2014, 3, 296-300.

62. Akbari, M.; Ownegh, M.; Asgari, H.R.; Sadoddin, A.; Khosravi, H. Desertification risk assessment and management program. Glob. J. Environ. Sci. Manag. 2016, 2, 365. [CrossRef]

63. Akbari, M.; Ownegh, M.; Asgari, H.; Sadoddin, A.; Khosravi, H. Design and Development of Early Warning System for Desertification and Land Degradation. Environ. Resour. Res. 2016, 4, 111-130. [CrossRef]

64. Zhou, P.; Ang, B.W.; Zhou, D.Q. Weighting and aggregation in composite indicator construction: A multiplicative optimization approach. Soc. Indic. Res. 2010, 96, 169-181. [CrossRef]

(C) 2018 by the authors. Licensee MDPI, Basel, Switzerland. This article is an open access article distributed under the terms and conditions of the Creative Commons Attribution (CC BY) license (http://creativecommons.org/licenses/by/4.0/). 